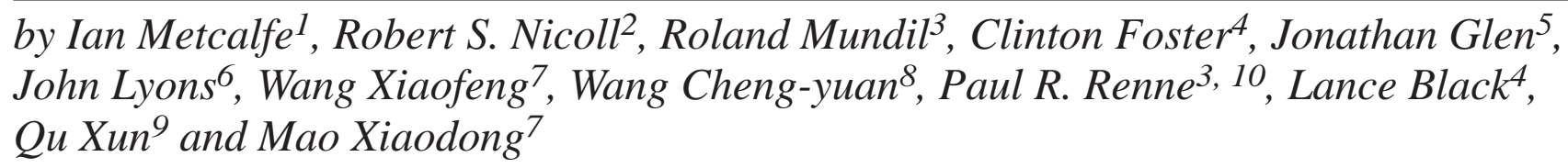

\title{
The Permian-Triassic boundary \& mass extinction in China
}

1 Asia Centre, University of New England, Armidale, NSW 2351, Australia.

2 Geology Department, Australian National University, Canberra ACT 0200, Australia.

3 Berkeley Geochronology Center, 2455 Ridge Road, Berkeley CA 94709, USA.

4 Australian Geological Survey Organisation, P.O. Box 378, Canberra 2601, Australia.

5 US Geological Survey, MS989, 345 Middlefield Road, Menlo Park, CA 94025, USA.

6 Dept of Earth Sciences, University of California, Santa Cruz, CA 95064, USA.

7 Centre for Stratigraphy and Palaeontology,CGS, 37 Gangyao Road,Yichang,Hubei,443003, PR.China.

8 Nanjing Institute of Geology \& Palaeontology, Academia Sinica, Chi-Ming-Ssu, 210008 Nanjing, China.

9. Institute of Geology and Mineral Resources, Xinjiang, MGMR 16 North Youhao Rd. Urumqi 830000, P.R.China

10. Dept. of Earth and Planetary Science, University of California, Berkeley CA 94709, USA

The first appearance of Hindeodus parvus (Kozur \& Pjatakova) at the Permian-Triassic (P-T) GSSP level (base of Bed 27c) at Meishan is here confirmed. Hindeodus changxingensis Wang occurs from Beds 26 to 29 at Meishan and appears to be restricted to the narrow boundary interval immediately above the main mass extinction level in Bed 25. It is suggested that this species is therefore a valuable P-T boundary interval index taxon. Our collections from the Shangsi section confirm that the first occurrence of Hindeodus parvus in that section is about $5 \mathrm{~m}$ above the highest level from which a typical Permian fauna is recovered. This may suggest that that some section may be missing at Meishan. The age of the currently defined Permian-Triassic Boundary is estimated by our own studies and a reassessment of previous worker's data at c. $253 \mathrm{Ma}$, slightly older than our IDTIMS ${ }^{206} \mathrm{~Pb}^{238} \mathrm{U}$ age of 252.5 \pm 0.3 Ma for Bed 28 , just $8 \mathrm{~cm}$ above the GSSP boundary (Mundil et al., 2001). The age of the main mass extinction, at the base of Bed 25 at Meishan, is estimated at slightly older than 254 Ma based on an age of >254 Ma for the Bed 25 ash. Regardless of the absolute age of the boundary, it is evident that the claimed $<165,000 y$ short duration for the negative carbon isotope excursion at the P-T boundary (Bowring et al., 1998) cannot be confirmed. Purportedly extraterrestrial fullerenes at the boundary (Becker et al., 2001) have equivocal significance due to their chronostratigraphic non-uniqueness and their occurrence in a volcanic ash.

\section{Introduction}

The boundary between the Permian and Triassic periods shows the most significant change in global biota in the Phanerozoic (and perhaps in the entire history of life on earth) and marks the boundary between the Palaeozoic and Mesozoic Eras. More than $90 \%$ of shelly marine genera were wiped out in this event and approximately $70 \%$ of animals and plants on land suffered similarly. Possible global catastrophic events suggested as causes of the P-T mass extinction include bolide impact, melting of gas hydrates flooding the world's atmosphere with methane, major marine regression, massive volcanism, oceanic anoxia and overturn of stagnant deep ocean waters (e.g. Erwin, 1993, 1994; Renne et al., 1995; Wignall and Twichett, 1996; Knoll et al., 1996; Hallam and Wignall, 1997; Rampino et al., 2000; Becker et al., 2001) or a combination thereof. The transition between the Permian and Triassic has proved to be notoriously difficult to study because there is a stratigraphic gap at this level in many parts of the world. Biostratigraphic correlation of marine and terrestrial sequences has proved inadequate to answer the question of whether the mass extinction events in the sea and on land were synchronous or not, or if the extinctions took place over a very short or longer time period. Magnetostratigraphic correlation of marine and terrestrial P-T boundary sequences is still not refined enough to effect precise correlation of mass extinction events and P-T boundary sequences belong to the Permo-Triassic Illawarra Mixed Megazone (Menning, 1995). In 1996 we began a major Australian Research Council funded multidisciplinary project on the Permian-Triassic Boundary and Mass Extinction. This ongoing project involves an international research team from Australia, China and the USA and is conducting radio-isotopic dating, biostratigraphical, magnetostratigraphical, and chemostratigraphical studies of PermianTriassic transition sequences in China. Our aims are to provide better constraints on the age of the P-T boundary, the age and correlation of the mass extinction in both marine and terrestrial sequences, a better Permian-Triassic timescale, constraints on the tempo of mass extinction and recovery events, and constraints on suggested causative mechanisms for ther P-T mass extinction.

The Global Stratotype Section and Point (GSSP) for the base of the Triassic and hence the Permian-Triasic/Palaeozoic-Mesozoic boundary has been formally established and ratified by the International Union of Geological Sciences (IUGS) at Section D, Meishan, Changxing County, Zhejiang Province, China (Yin et al., 2001).

We have so far conducted work on the Permian-Triassic Boundary GSSP section and paratype marine sections at Meishan, Zhejian Province, on the ancillary P-T boundary section at Shangsi, Sichuan Province, and on important terrestrial sequences at Dalongkou and Lucaogou, Xinjiang Province (Figure 1) and here present some observations and initial results of our ongoing studies. 


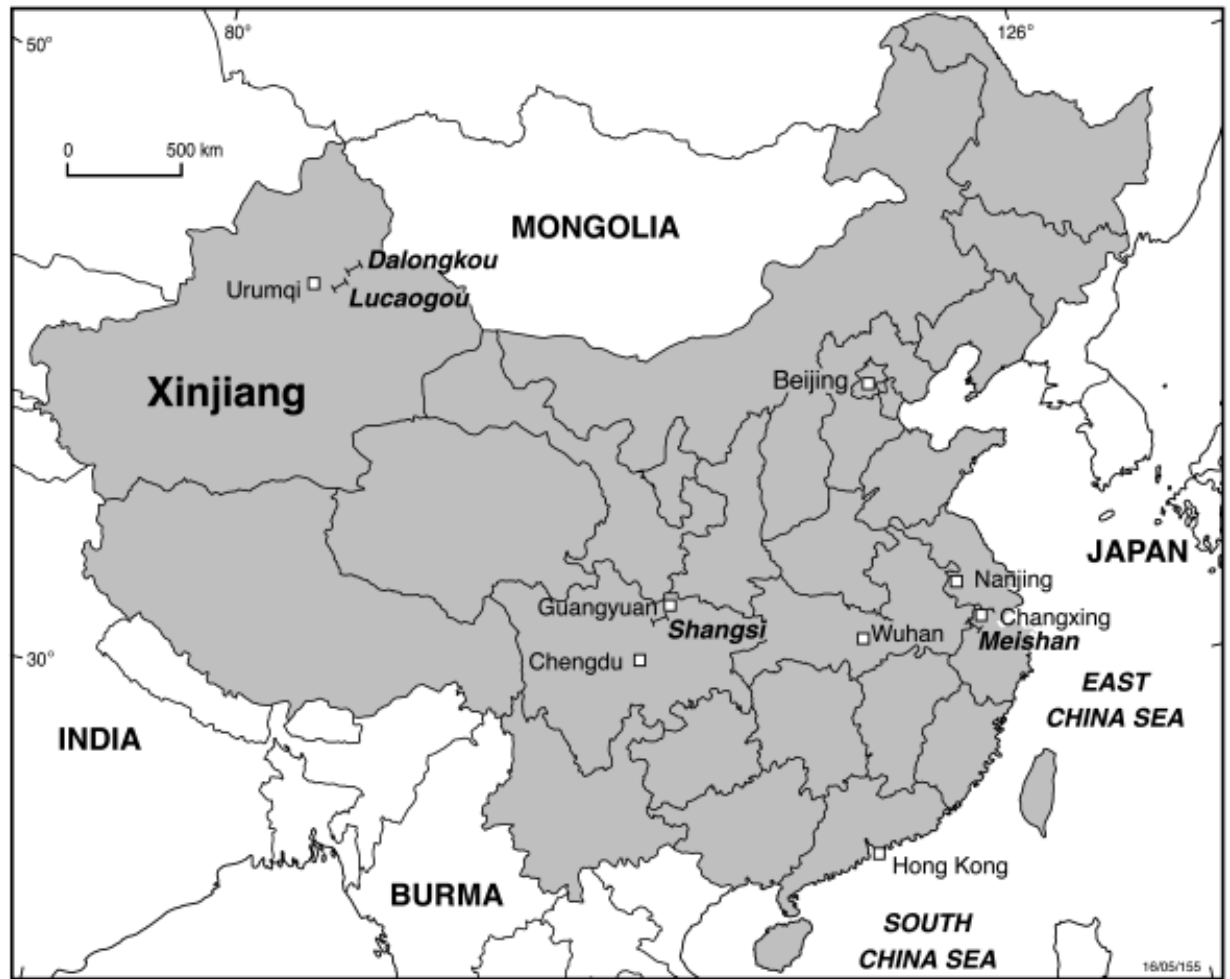

Figure 1 Location of Meishan, Shangsi, Dalongkou, and Lucaogou sections.

\section{Lithostratigraphy}

Extensive fieldwork on the Permian-Triassic boundary stratotype (GSSP) and parastratotype sections at Meishan, Zhejiang, East China, at the important ancillary boundary section at Shangsi, Sichuan, Southwest China, and at the Dalongkou and Lucaogou nonmarine sections near Jimsar and Urumqi, Xinjiang Province, Northwest China has been undertaken. Detailed stratigraphic logs were measured for sampled sections as part of this work. Sampled sections at Meishan and Shangsi were re-measured and tied in to previous measured sections and "bed" numbers of Chinese colleagues. Numerous volcanic ash/clay layers were logged in the P-T transitional interval and from the Changhsingian and Wuchiapingian stages in the Permian and the Induan of the Triassic, and sampled for radio-isotopic dating (see below).

One of the best non-marine Permian-Triassic transition sedimentary rock sequences in the world is found in the southern Junggar Basin in the northern foothills of the Bogda Shan (a segment of the Tien Shan), Xinjiang Province, NW China. This lacustrine-fluviatile sequence contains rich palynomorph floras and vertebrate faunas enabling identification of the Permian-Triassic transitional level within the sequence. Much detailed work has already been undertaken on these sequences by Chinese geologists but relatively little of this is available in the English language. In addition, detailed stratigraphic $\operatorname{logs}$ through this critical interval are generally lacking. In late 2000, we undertook a field expedition to Xinjiang as part of this project. Our detailed measured sections from Dalongkou and Lucaogou will be presented elsewhere but a highly simplified stratigraphic section through the Guodikeng Formation is presented in Figure 4. represent 100 microns.

\section{Biostratigraphy}

Biostratigraphic work has mainly centred on providing biostratigraphic control of ash beds sampled for radio-isotopic dating and on the P-T transitional interval to provide ancillary information around the P-T boundary and mass extinction level. Work on conodonts from the Permian-Triassic transition beds has confirmed the first appearance of Hindeodus parvus (Kozur \& Pjatakova) at the GSSP level (base of Bed 27c) at Meishan. In addition, our work has highlighted the value of Hindeodus changxingensis Wang (Figure 2b) as a P-T transition level index species. This species occurs from Beds 26 to 29 at Meishan and appears to be restricted to the narrow boundary interval immediately above the main mass extinction level in Bed 25 (Figure 3). Our taxonomic work has also revealed the presence of three new species of Hindeodus, Hindeodus n. sp. A, Hindeodus n. sp. B, Hindeodus n. sp. C (Nicoll et al., in press), and up to five new species of Isarcicella in the latest Permian and earliest Triassic providing new information on the evolution of these two biostratigraphically important conodont genera is being prepared for publication.
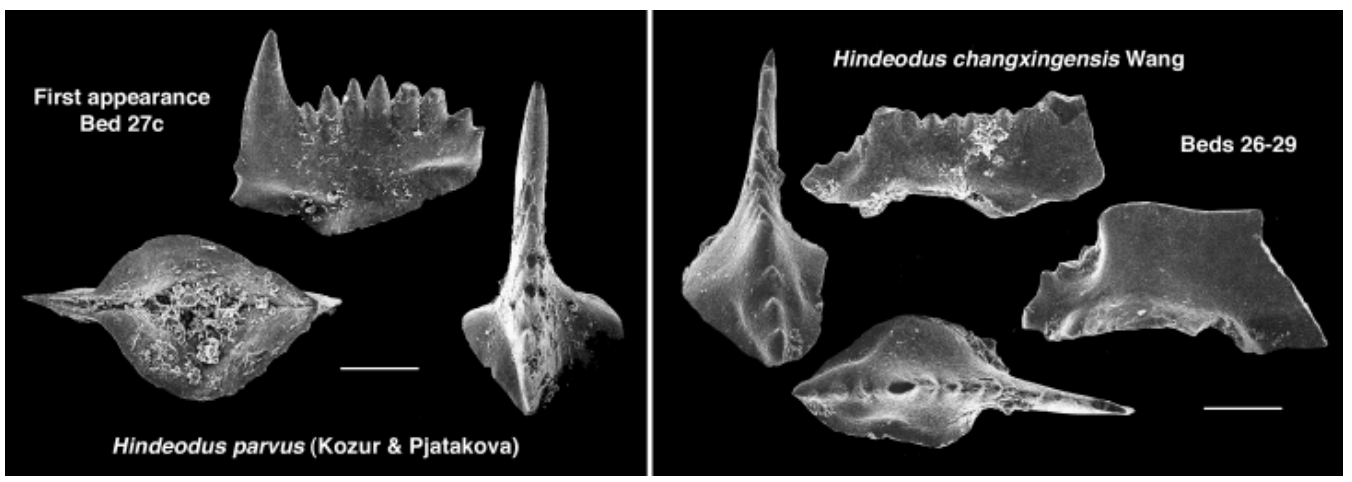

Figure 2 Hindeodus parvus (Kozur \& Pjatakova) \& Hindeodus changxingensis Wang. Scale bars 


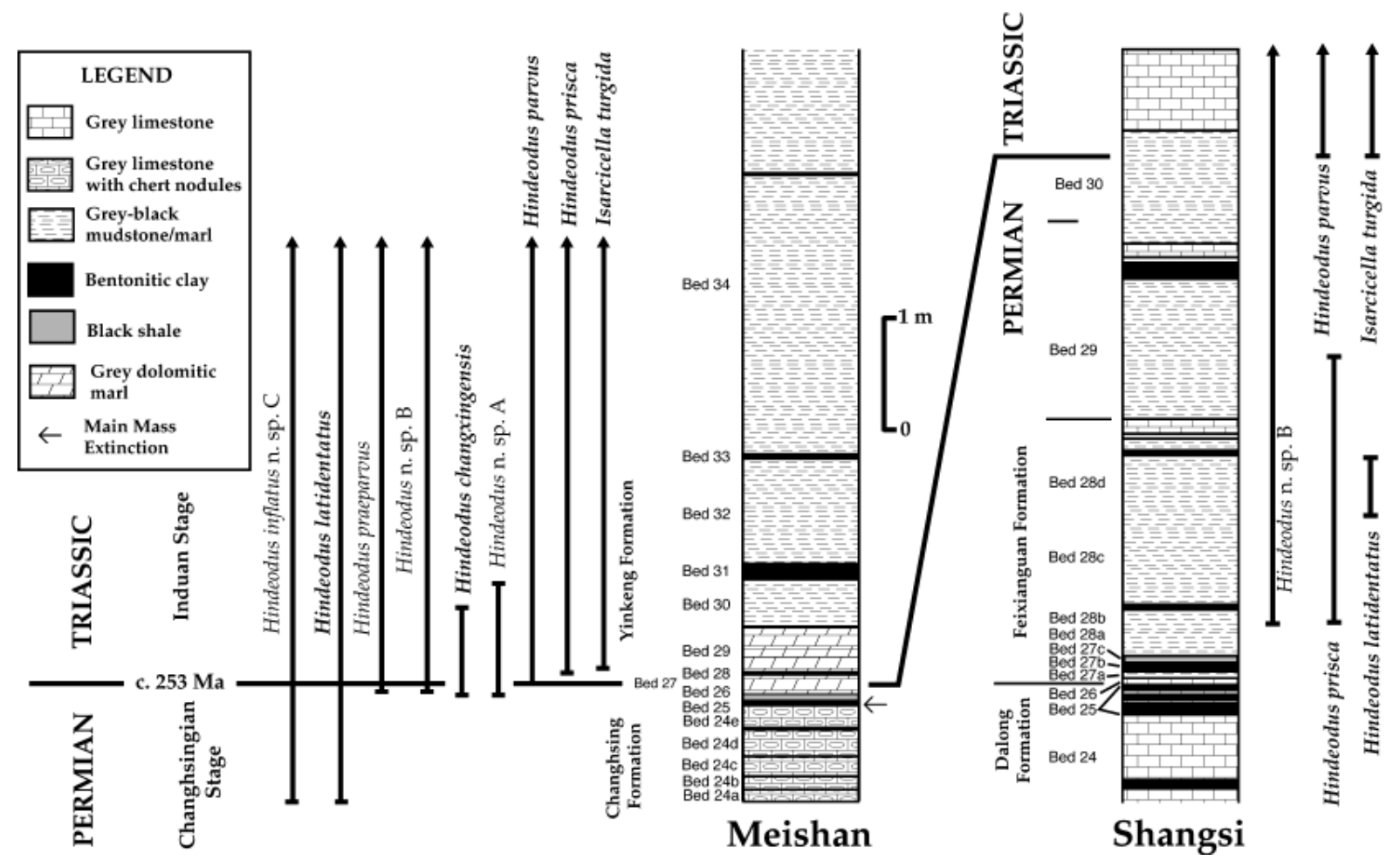

Figure 3 P-T boundary sections at Meishan and Shangsi showing first appearance of $H$. parvus and range of $H$. changxingensis and other important species of Hindeodus. Ages for Bed 28 and Bed 25 at Meishan, and interpreted age of the P-T boundary from Mundil et al. (2001). Bed numbers for Meishan from Yin et al. (1996) and for Shangsi from Lai Xulong et al. (1996). Bed numbers in the two sections do not equate with one another.

Our collections from the Shangsi section confirm the observation of Dai \& Zhang (1989) that the first occurrence of Hindeodus parvus in that section is about $5 \mathrm{~m}$ above the highest level from which a typical Permian fauna is recovered. This suggests that the P-T boundary is higher than previously interpreted at Shangsi or that some section may be missing at Meishan. Examination of this problem is continuing.

In addition, limited work has also been undertaken on foraminifers and ostracods. Samples from non-marine sections in Xinjiang have produced some excellent palynofloras and systematic evaluation of these is underway.

Ninety samples were collected from surface sections for palynological and organic carbon isotopic analysis: 63 from the Dalongkou Anticline (44 from the North Limb, and 19 from the South Limb), and 27 from the Lucaogou section. Like previous authors, we are attempting to better define the P/T boundary in this non-marine section. Most samples are from the Guodikeng Formation, with fewer in the overlying Early Triassic Jiucaiyaun Formation, and in the older Upper to Middle Permian formations, from the Wutonggou to Lucaogou units (see summary by Ouyang et al., 1999).

Because the samples are from outcrop, recovery of plant microfossils is variable, Ouyang \& Norris (1999) for example processed $100 \mathrm{~g}$ of each of nine samples from the North Limb of the Dalongkou Anticline and recovered assemblages from only three. Based on the occurrence of Aratrisporites sp. together with probable lycopod spores belonging to Lundbladispora spp., Ouyang \& Norris suggest that the P/T boundary occurs within the upper Guodikeng Formation, 40-50 $\mathrm{m}$ below the base of the Jiucaiyaun Formation. Their study confirms earlier suggestions by Li (in Yang et al, 1986), and $\mathrm{Wu}$ (1989), although Yang et al. did not report Aratrisporites sp. from the upper Guodikeng Formation. We too have not yet recorded the genus, but repeat samples are being prepared.

Our study is attempting to: locate the palynofloral boundary in relation to any changes in palaeomagnetic reversals, test the relationship between floral change and changes in carbon isotopic com- position; and test correlation potential between key marine and nonmarine sections.

Early results have shown an association between occurrences of the ?algal/fungal remains assigned Tympanicysta Balme 1980 and Estherid-bearing beds within the lower Guodikeng, in both sections of the Dalongkou Anticline. The FAD of Tympanicysta may act as an event marker in the Dalongkou section, but correlation with the Changhsing Formation in the Meishan section (see Ouyang \& Utting 1990), based on this genus seems premature. Foster et al. (1998) noted that from the stratigraphic distribution of the genus, and probable cogeners, it might be a disaster taxon, rather than a unique time marker. Moreover, Krassilov et al. (1999) have pointed out that the biologic origin of the genus is uncertain. It is often considered to be fungal, but they suggest it may be similar to an extant zygnematalean green alga such as Spirogyra. As a consequence, blooms may occur in response to ponding events, associated with the early stages of the Late Permian global transgression. This explanation may not account for all records, and as part of this study, we are re-examining both Late Permian and Early Triassic occurrences of Tympanicysta, and cogeners.

\section{Isotope geochronology}

Fifty samples of volcanic ash/clay layers were collected from the stratotype and parastratotype sections near Meishan and Shangsi, for radio-isotopic analysis. Zircons from selected ash/clay samples have been dated by SHRIMP (Sensitive High Resolution Ion Microprobe) and IDTIMS (Isotope Dilution Thermal Ionisation Mass Spectrometry) techniques. In addition, felspars have been extracted for $\mathrm{Ar}-\mathrm{Ar}$ dating. 550 individual SHRIMP analyses of zircons from five ash layers spanning the P-T boundary have been undertaken on SHRIMP II at the ANU. The result are currently being compiled and interpreted with simultaneous consideration of potential biases imposed by using various SHRIMP zircon standards. We note here 
Bethulie, Karoo basin, South Africa

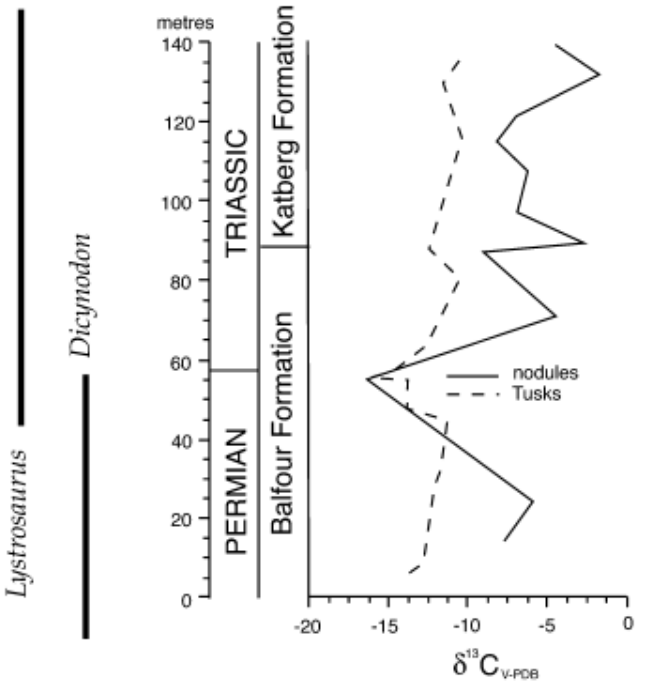

Buff cross-bedded sandstone

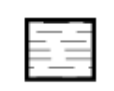

Chocolate Brown/Purple/ green Mudstones with thin sanstone interbeds

Green/grey sandstone with subordinate mudstone

\section{$\oint$ Calcareous Nodules}

Dark Grey Shales/Siltstones

with thin sandstone interbeds

Dalongkou (South Limb), Xinjiang, China
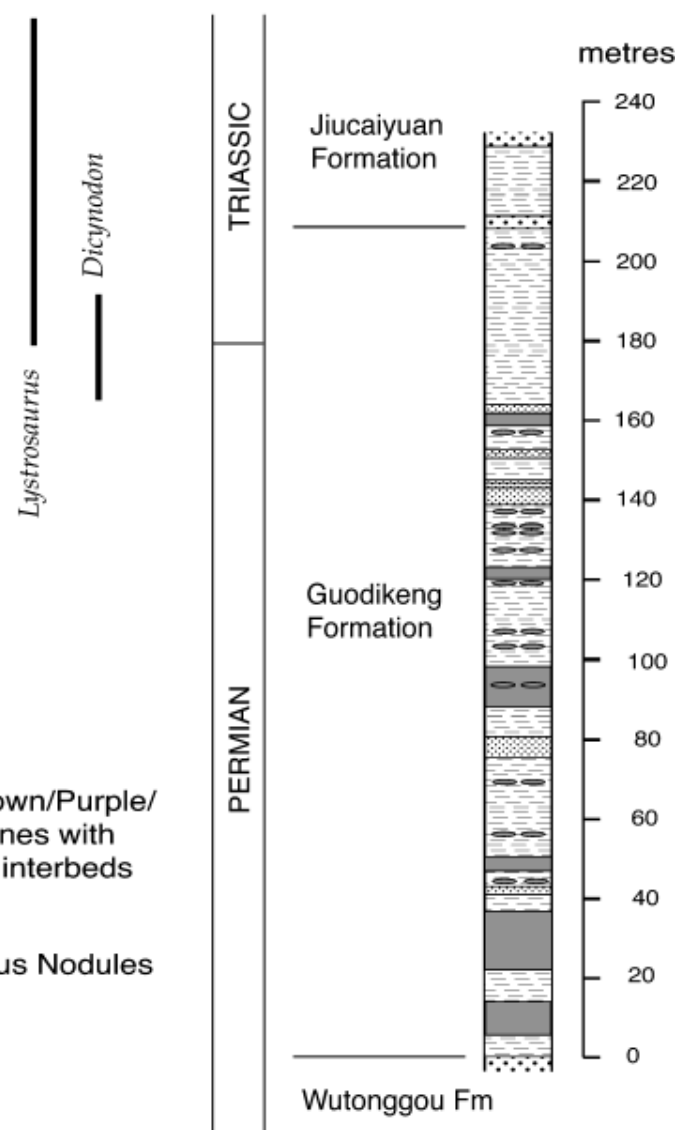

Figure 4 P-T boundary $\delta^{13}$ C curves in the Karoo basin, South Aftrica (MacLeod et al., 2000) showing cooincidence with the negative excursion and overlap of the vertebrate genera Dicynodon and Lystrosaurus, and comparison with the similar overlap at Dalongkou, China.

that Yin et al. (2001) have quoted new SHRIMP dates in their recent Episodes overview paper on the P-T boundary GSSP and they attribute these dates to Metcalfe et al. (1999). These dates have never been published and were not presented in the abstract of Metcalfe et al. (1999). We urge all those interested in our new SHRIMP isotopic data to wait for formal publication of the results and not to use the dates published by Yin et al. (2001) which were preliminary results presented orally at a meeting in Wuhan. IDTIMS single grain analyses with a precision at the per mil level undertaken at the Berkeley Geochronology Center demostrate that zircon populations from ash beds in the Permian-Triassic boundary transition at Meishan, China show subtle inter- and intra-grain heterogeneities including inheritance, and lead loss effects. If multi-grain IDTIMS analyses are applied to such zircon populations the biases can become impossible to recognise because of resulting age-averaging. In addition, pooling of such multigrain analyses can produce biased ages with very small, understated uncertainties. Ages reported by Bowring et al. (1998) for individual layers from Meishan, appear to be underestimated by as much as $1 \%$. The age of the currently defined Permian-Triassic Boundary is estimated by our own studies and a re-assessment of previous worker's data at ca. $253 \mathrm{Ma}$, slightly older than our IDTIMS ${ }^{206} \mathrm{~Pb} / 238 \mathrm{U}$ age of $252.5 \pm 0.3 \mathrm{Ma}$ for Bed 28 , just $8 \mathrm{~cm}$ above the GSSP boundary (Mundil et al., 2001). The age of the main mass extinction, at the base of Bed 25 at Meishan, is estimated at slightly older than $254 \mathrm{Ma}$ based on an age of $>254 \mathrm{Ma}$ for the Bed 25 ash. These results are confirmed by initial zircon-age data from an ash layer immediately below the boundary interval from the Shangsi section. Regardless of the absolute age of the boundary, it is evident that the claimed $<165,000$ y short duration for the negative carbon isotope excursion at the P-T boundary (Bowring et al., 1998) cannot be confirmed by new isotopic data (Mundil et al., 2001). Owing to the pervasiveness of Pb-loss in Meishan bentonites, it appears likely that the Ar/Ar system offers the best prospect for determining the duration of P-T boundary events. As shown by previous work (Renne et al., 1995), ${ }^{40} \mathrm{Ar} /{ }^{39} \mathrm{Ar}$ analysis of feldspars is at least as capable as $\mathrm{U} / \mathrm{Pb}$ for high-resolution dating of these bentonites. We note here that Yin et al. (2001) have stated that they "temporarily use" an age of $251 \mathrm{Ma}$ for the P-T boundary. The age of $251 \mathrm{Ma}$ was arrived at by averaging ages for the "boundary clay" Bed 25 at Meishan from SHRIMP and conventional U-Pb and $\mathrm{Ar}-\mathrm{Ar}$ isotopic methods. Since there is a known systematic bias between these different isotopic systems, this averaging exercise is meaningless. We reiterate that the best estimate for the age of the P-T boundary is $253 \mathrm{Ma}$ as presented by Mundil et al. (2001).

\section{Palaeomagnetism}

The position of the P-T boundary and mass extinction level, with respect to magnetic polarity is equivocal, with some authors placing this within a normal chron slightly above the reversal boundary (eg. Menning, 1995) and others placing the boundary precisely coincident with a reversed to normal boundary (eg. Steiner et al., 1989).

At Meishan, in the Permian-Triassic Boundary GSSP section and paratype marine sections, the P-T boundary, and the mass extinction events are reported to occur within a normal chron (Li and Wang, 1989). Our project involves detailed magnetostratigraphic studies, integrated with detailed biostratigraphy and radio-isotopic ages, aimed at resolving this and to assist in precise correlation of the 
P-T boundary and mass extinction level(s) in marine and terrestrial sequences.

During our current study, 915 samples were collected from marine and non-marine P-T sections at Shangsi, Sichuan and near Jimsar and Urumqi, Xinjiang Province, China. These samples are currently undergoing detailed analysis.

\section{Magnetostratigraphy of the Dalongkou and Lucaogou sections, NW China}

We have sampled three late Permian to early Triassic terrestrial sections in the southern Junggar basin of northwest China in an attempt to correlate this terrestrial record of the Permo-Triassic boundary with the nearby Shangsi marine type-section. Two of the sections (Dalongkou north and south) come from opposing limbs of an eastwest trending anticline and are separated by approximately two kilometers, while the third (Lucaogao) comes from a monocline approximately $100 \mathrm{~km}$ to the west. To date, these sections are loosely correlated based on lithostratigraphy.

We have performed complete stepwise thermal demagnetization on over 230 samples from the three sections; these data reveal that the sections span both normal and reverse polarity intervals. Despite strong present field overprinting, our magnetic directions pass a fold test and our rock magnetic data indicate that titanomagnetite dominates the magnetic mineralogy in a majority of samples. Lithostratigraphic and magnetostratigraphic correlations between these sections are consistent and indicate that the composite section consists of five polarity chrons.

Compilation of global Permo-Triassic (P-T) magnetostratigraphy (Jin et al., 2000) identifies a reverse-to-normal polarity transition roughly coincident with the Paleozoic-Mesozoic boundary. Results from Shangsi (Heller et al., 1988; Steiner et al., 1989; Heller et al., 1995) are consistent with this determination; the reversal boundary is indistinguishable from the bio/lithostratigraphic boundary. At both Dalongkou and Lucaogou measured sections, however, the nearest correlative reverse-to-normal polarity transition lies significantly below the previously inferred P-T boundary (Ouyang and Norris, 1997). Provided that the marine magnetostratigraphy is correct, this indicates that the boundary has been misplaced; the simplest interpretation of our data locates the boundary close to the prominent lithologic boundary between the Wutonggou and Guodikeng formations. This pick for the Permo-Triassic reversal minimizes the descrepancy between the previously inferred P-T boundary and the nearest possible reversal; it does not preclude the possibility that the boundary lies either further below our pick or well above the studied sections. These results suggest that future sampling and study should focus on the contact between the Wutonggou and Guodikeng formations.

\section{Chemostratigraphy}

It has been claimed that a "spike" or shift in carbon isotope compositions of marine carbonates that immediately postdates the mass extinction in the marine environment (Baud et al., 1989) can also be used in terrestrial sequences to identify the P-T boundary (Morante et al., 1994). Foster et al. (1997) and Foster et al. (1999) have however issued a warning regarding such correlations, as isotopic composition of organic matter in terrestrial sediments appears to be overprinted by contributions from different parent plant types. The stratigraphic position, degree of the negative $\delta^{13} \mathrm{C}$ isotopic shift, and its duration appear equivocal (see and compare Bowring et al., 1998 Figure 2; Jin et al., 2000, Figure 4). In non-marine sections, the relationship between $\delta^{13} \mathrm{C}$ variations and the P-T boundary is not well established. MacLeod et al. (2000) have demonstrated that a $\delta^{13} \mathrm{C}$ negative excursion in the Karoo Basin of South Africa occurs within a $15 \mathrm{~m}$ zone of overlap of the mammal-like reptile genera Dicynodon and Lystrosaurus and just below the extinction level of Dicynodon which they equate with the P-T boundary (Figure 4). A similar over- lap of Dicynodon and Lystrosaurus occurs at Dalongkou, Xinjiang Province, China (Figure 4) and we have collected suites of samples from the various non-marine P-T boundary sections at Dalongkou and Lucaogou, and from marine sections at Meishan and Shangsi, for carbon isotope studies aimed at resolving the equivocal nature of the curve and at correlating marine and non-marine sequences.

Becker et al. (2001) recently reported fullerene-hosted helium and argon with isotopic compositions suggestive of an extraterrestrial origin from Bed 25 at Meishan. We note that this horizon is the same bentonite used for our geochronologic analyses as noted above, and that this unit appears to be purely volcanic in origin, with scant traces of reworked sedimentary material. The presence of possibly extraterrestrial fullerenes in such a deposit is perplexing, and suggests a need for further work to clarify the significance of this occurrence. We note further that Meishan Bed 25 cannot be precisely correlated biostratigraphically with the Sasayama section in Japan. Thus the Sasayama and Meishan fullerene spikes reported by Becker et al. (2001) may not represent a single event, and their significance must be evaluated through further work to establish their distribution.

\section{Acknowledgements}

We would like to acknowledge the kind assistance of the Xinjiang Bureau of Geology during our field investigations at Dalongkou and Lucaogou. Financial support, as a Large Australian Research Council Grant to I. Metcalfe, is also gratefully acknowledged. We also acknowledge support to the Berkeley Geochronology Center from the Ann and Gordon Getty Foundation and facilities and support provided by the Australian Geological Survey Organisation.

\section{References}

Baud, A., Magaritz, M., and Holser, W. T., 1989, Permian-Triassic of the Tethys: Carbon isotope studies. Geologische Rundschau 78, 649-77.

Becker, L., Poreda, R., Hunt, A. G., Bunch, T. E., and Rampino, M. 2001, Impact Event at the Permian-Triassic Boundary: Evidence from Extraterrestrial Noble Gases in Fullerenes. Science 291, 1530-1533.

Bowring, S. A., Erwin, D. H., Jin, Y. G., Martin, M. W., Davidek, K., and Wang, W., 1998, U/Pb Zircon Geochronology and tempo of the End-Permian Mass Extinction. Science, 280, 1039-1045.

Erwin, D. H., 1993, The great Paleozoic crisis: life and death in the Permian. Columbia Univ. Press.

Erwin, D. H., 1994, The Permo-Triassic extinction. Nature 367, 231-236.

Farley, K. A., and Mukhopadhyay, S., 2001, An Extraterrestrial Impact at the Permian-Triassic Boundary? Technical Comments. Science, 293, 2343a.

Foster, C. B., Logan, G. A., and Summons, R. E., 1998, The Permian-Triassic boundary in Australia; where is it and how is it expressed? 110, $247-266$.

Foster, C. B., Logan, G. A., and Summons, R. E., 1999, The Permian-Triassic boundary in Australia: Organic carbon isotopic anomalies relate to organofacies, not a biogeochemical "event". Ninth Annual V.M. Goldshmidt Conference: Lunar and Planetary Institute Contribution No. 971, $87-88$.

Foster, C. B., Logan, G. A., Summons, R. E., Gorter, J. D. and Edwards, D. S., 1997, Carbon isotopes, kerogen types and the Permian-Triassic boundary in Australia: implications for exploration. APPEA Journal, 1997, 472-489.

Hallam, A., and Wignall, P. B., 1997. Mass Extinctions and Their Aftermath. Oxford University Press.

Heller, F., Haihong, C., Dobson, J., and Haag, M., 1995, Permian-Triassic magnetostraigraphy — new results from South China. , 89, 281-295.

Heller, F., Lowrie, W., Huamei, L., and Junda, W., 1988, Magnetostratigraphy of the Permo-Triassic boundary section at Shangsi (Guangyuan, Sichuan Province, China), , 88, 348-356.

Isozaki, Y., An Extraterrestrial Impact at the Permian-Triassic Boundary? Technical Comments. Science 293, 2343a.

Jin, Y. G., Shang, Q., and Cao, C., 2000. Late Permian magnetostratigraphy and its global correlation. , 45, 698-704.

Jin, Y. G., Wang, Y., Wang, W., Shang, Q. H., Cao, C. Q., and Erwin, D, H., 2000, Pattern of Marine Mass Extinction Near the Permian-Triassic Boundary in South China. Science, 289, 432-436.

Knoll, A. H., Bambach, R. K., Canfield, D. E., and Grotzinger, J. P., 1996, Comparative Earth history and Late Permian mass extinction. Scinece, $273,452-57$. 
Krassilov, V. A., Afonin, S. A., and Barinova, S. S., 2000, Tympanicysta and the terminal Permian events. Permophiles, 35, 16-17.

Lai Xulong, Yang Fengqing, Hallam, A., and Wignall, P. B., 1996, The Shangsi section, candidate of the Global Stratotype Section and Point of the Permian-Triassic Boundary. Pp. 113-124 in, Yin Hongfu ed., The Palaeozoic-Mesozoic Boundary candidates of Global Stratotype Section and Point of the Permian-Triassic Boundary. China University of Geosciences Press, Wuhan.

Li Huamei, and Wang Junda, 1989, Magnetostratigraphy of Permo-Triassic boundary section of Meishan of Changxing, Zhejiang. Science in China 8, 652-658 (in Chinese with English abstract).

MacLeod, K. G., Smith, R. M. H., Koch, P. L., and Ward, P. D., 2000, Timing of mammal-like reptile extinctions across the Permian-Triassic boundary in South Africa. Geology 28, 227-230.

Menning, M., 1995, A numerical time scale for the Permian and Triassic Periods: an integrated time analysis. Pp. 77-97 in: Scholle, P.A., Peryt, T.M. and Ulmer-Scholle, D.S. (eds), The Permian of Northern Pangea, Springer-Verlag.

Morante, R., Veevers, J. J., Andrew, A. S and Hamilton, P. J., 1994, Determination of the Permian-Triassic boundary in Australia from carbon isotope stratigraphy. APEA Journal, 34, 330-36.

Mundil, R., Metcalfe, I., Ludwig, K.R., Renne, P.R., Oberli, F. and Nicoll, R.S. 2001. Timing of the Permian-Triassic biotic crisis: Implications from new zircon $\mathrm{U} / \mathrm{Pb}$ age data (and their limitations). Earth and Planetary Science Letters, 187, 133-147.

Nicoll, R. S., Metcalfe, I., and Wang Cheng-yuan, In press, New species of the conodont Genus Hindeodus and the conodont biostratigraphy of the Permian-Triassic boundary interval. Journel of Asian Earth Sciences.

Ouyang, S., and Norris, G., 1999, Earliest Triassic (Induan) spores and pollen from the Junggar Basin, Xinjiang, northwestern China. Review of Palaeobotany and Palynology. 106, 1-56.

Ouyang, S., and Utting, J., 1990, Palynology of Upper Permian and Lower Triassic rocks, Meishan, Changxing County, Zhejiang Province, China. Review of Palaeobotany and Palynology, 66, 65-103.

Ouyang, S., Zho, Y., Wang, Z., and Zhan, J., 1999, Palynostratigraphic correlation of the Permian System of northern Xinjiang and the Cis-Urals. Permophiles, 33, 24-27.

Ian Metcalfe holds $B S c$ and $P h D$ degrees from Durham and Leeds, U.K. He worked at Universities in Malaysia from 1977-1989 and is currently Associate Professor and Deputy Director, Asia Centre, University of New England, Australia. He was Australian Science Coordinator for the International Ocean Drilling Program (1992-1995), Secretary (1996-2000) and Titular Member (1996-2004) of the IUGS Subcommission on Carboniferous Stratigraphy, and Co-Leader of IGCP Projects 321 (1991-1996) and 411 (19982002). He is on the Science Advisory Council, Centre for Stratigraphy and Palaeontology, China Geological Survey. Research interests relate to conodonts; Carboniferous, Permian and Triassic stratigraphy; tectonic evolution and palaeogeography of East Asia; and the Permian-Triassic boundary and Mass Extinction.
Rampino, M. R., Prokoph, A., and Adler, A., 2000, Tempo of the end-Permian event: High-resolution cyclostratigraphy at the Permian-Triassic boundary. Geology, 28, 643-646.

Renne, P. R., Zichao, Z., Richards,M. A., . Black,M. T., and Basu, A. R. 1995, Synchrony and causal relations between Permian-Triassic Boundary crises and Siberian flood volcanism, Science, 269: 1413-1413.

Steiner, M., Ogg, J., Zhang, Z. K., and Sun, S., 1989, The Late Permian/Early Triassic magnetic polarity time scale and plate motions of South China. Jour. Geophys. Res. 94 (B6), 7343-7363.

Wignall, P. B., and Twichett, R. J., 1996, Oceanic anoxia and the end Permian mass extinction. Science, 272, 1155-58.

Wu, S. Z., 1989, Determination of the P-T boundary and its correlation at home and abroard. Pp. 85-100 in Research on the boundary between Permian and Triassic in Tianshan Mountain of China. China Ocean Press, Beijing.

Yang Jiduan, Qu Lifan, Zhou Huiqin, Cheng Zhengwu, Zhou Tongshun, Hou Jingpeng, Li Peixian, Sun Suying, Li Yougui, Zhang Yuxiu, Wu Xiaozu, Zhang Zhimin, Wang Zhi, 1986, Permian and Triassic strata and fossil assemblages in the Dalongkou area of Jimsar, Xinjiang. Geological memoirs Series 2 (3)

Yin Hingfu, Wu Shunbao, Ding Meihua, Zhang Kexin, Tong Jinnan, Yang Fengqing, and Lai Xulong, 1996, The Meishan section, candidate of the Global Stratotype Section and Point of Permian-Triassic Boundary. pp. 31-48 in Yin Hongfu ed., The Palaeozoic-Mesozoic Boundary candidates of Global Stratotype Section and Point of the Permian-Triassic Boundary. China University of Geosciences Press, Wuhan.

Yin Hingfu, Zhang Kexin, Tong Jinnan, Yang Zunyi, and Wu Shunbao, 2001, The Global Stratotype Section and Point (GSSP) of The PermianTriassic Boundary. Episodes, 24, 102-114.

Robert S. Nicoll was educated in the USA and obtained his PhD from the University of Iowa in 1971. He worked for many years as Principal Research Scientist at the Australian Geological Survey Organisation and is currently Visiting Research Fellow at the Australian National University. His research interests centre mainly on the multi-element taxonomy, colour alteration, palaeobiology, and biogeography of conodonts; Ordovician stratigraphy and biostratigraphy; Australian hydrocarbon-bearing basins; and more recently, Permian-Triassic stratigraphy and the P-T boundary.

Roland Mundil is at the Berkeley Geochronology Center (Berkeley, California). In close collaboration with Ken Ludwig and Paul Renne his recent research has been focused on the understanding and refinement of radio-isotopic dating techniques and their application to a variety of shortterm events and processes in Earth's history, among them the terminal Paleozoic biotic crisis, orbital signals recorded in sediments and large-scale volcanic events.
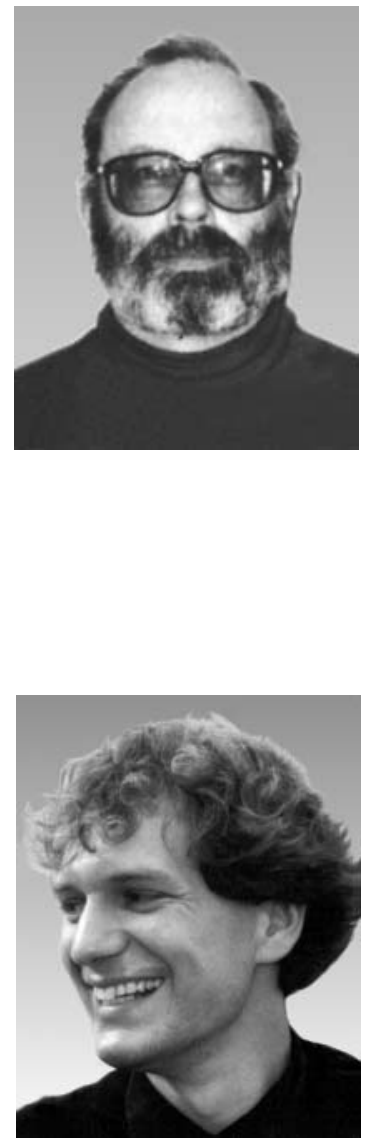